\section{Australian panel lays plans for emissions trading}

An independent review of climate change in Australia has laid out suggestions for how the country might construct an emissionstrading scheme.

On 4 July, economist Ross Garnaut released a draft of the report commissioned by the Labor government of Prime Minister Kevin Rudd. Although the final report is not due until September, the draft outlines Garnaut's suggestions for how emissions trading could begin in 2010 .

The report urges the government to include as many sectors as possible, including transportation, and to auction off carbon permits. Of the revenue generated, it recommends that $50 \%$ should go to households to offset resulting rises in energy prices, $30 \%$ to business, and $20 \%$ to research and commercialization of new technologies.

A government green paper outlining trading-scheme plans ahead of legislation is due this month, and will "take into account Garnaut's views", says climate-change minister Penny Wong.

\section{UK physicists discover full scope of budget cuts}

Britain will try to sell $50 \%$ of its observing time on the Gemini telescopes to help make up for an $£ 80$-million (US\$157-million) budget shortfall, the Science and Technology Facilities Council (STFC) revealed last week. Funding for astronomy, particle physics and space science are all to be cut.

The council says it will be "reviewing our future involvement in Gemini”. It also slashed the UK contribution to ExoMars, a European-led mission to the red planet, by $25 \%$. Britain had been contributing about $£ 80$ million, one-tenth of the mission's overall budget.

The STFC claimed the funding package would secure the future of Britain's Jodrell Bank radio astronomy facility, which had been in some doubt.

The council scaled down a proposed $25 \%$ reduction in $\mathrm{UK}$ funding for the $\mathrm{LHCb}$

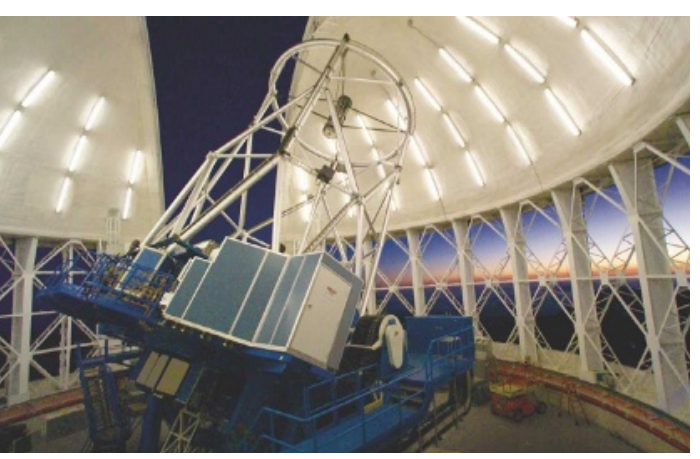

UK physicists face cuts on the Gemini telescopes.

\title{
Iranians face nuclear-study ban in the Netherlands
}

The Dutch government has enacted legislation blocking Iranian nationals' access to courses and facilities related to rocketry and nuclear technology.

Under the law, Iranians living in the Netherlands, including those holding dual citizenship, will need to seek a government waiver to take courses at master's level and above in nine different subjects, including gas turbines for uranium enrichment and reactor technology. They will

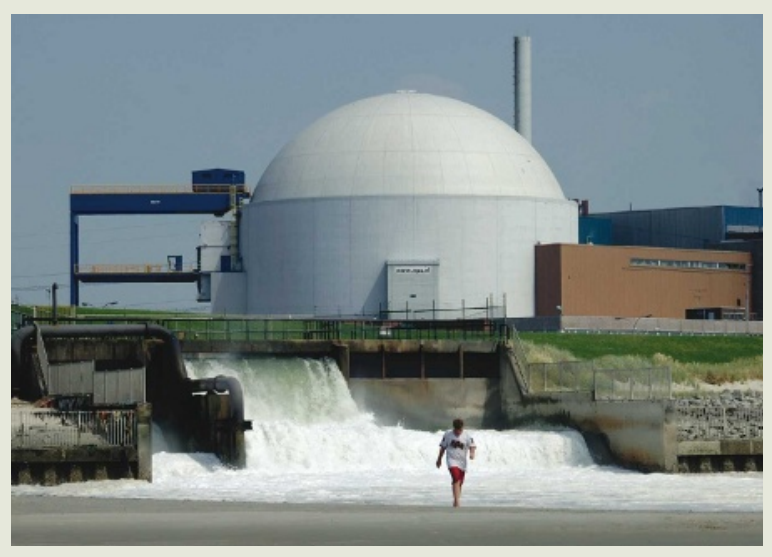
also be banned from the Borssele nuclear power plant (pictured) and four other nuclear facilities, says Rob Dekker, a spokesman for the Dutch Ministry of Foreign Affairs. The move comes in response to United Nations and European Union resolutions calling for restrictions on Iran's access to nuclear and weapons-related technology.

experiment at the Large Hadron Collider at CERN, Europe's particle-physics laboratory near Geneva. Amid concerns that such cuts would do "unacceptable damage" to the project, funding will be reduced instead by $5 \%$ in the project's first year and $10 \%$ in subsequent years.

\section{India takes pole position to study climate change}

A year after sending its first fully fledged expedition to the Arctic (see Nature 448, 642-643; 2007), India has established a research station in Svalbard, about 1,200 kilometres from the North Pole.

Officials signed an agreement with the Norwegian Polar Institute on 1 July to establish the base, called Himadri. The base will be managed by the National Centre for Antarctic and Ocean Research in Goa, which already maintains two research stations in Antarctica.

Research at the Arctic base will take place all year-round and will focus on climate change, officials say.

\section{Training for human studies may become mandatory}

The US government may soon require, rather than just recommend, that federally funded investigators, and the ethics-board members who approve their research, receive training and education in how to protect participants in human studies.

The Office for Human Research Protections (OHRP) announced last week that it is soliciting comments on whether such training in research ethics should be mandatory - and asking for estimates of what this would cost grantee institutions.
"Over the past several years, OHRP has identified serious, systemic noncompliance with the requirements ... for the protection of human subjects at a significant number of major institutions," OHRP regulators wrote in its Federal Register announcement on 1 July.

Interested parties now have until 29 September to submit their comments to humansubjectstraining@hhs.gov.

\section{Texas educator sues over job loss and creationism}

A former Texas official is suing the state's education agency, saying that its policies passively endorse creationism.

In a complaint filed with a district court on 1 July, Christina Comer, a former director of state science education, alleged that officials tacitly condone the teaching of creationism through a policy of neutrality. Comer oversaw Texas's science curriculum until last November, when she was forced to resign for circulating a notice of a talk entitled "Inside Creationism's Trojan Horse". In her termination notice, Comer was told that the education agency endeavoured to "remain neutral" on the issue of creationism.

Comer's complaint argues that board neutrality violates the separation of church and state. She is also seeking reinstatement to her former position.

\section{NPG ARCHIVING FOR AUTHORS}

Nature Publishing Group announced this week that it will provide a free service to help authors fulfil funder and institutional mandates for the archiving of primary research papers. NPG has encouraged self-archiving since 2005 . The new arrangements will provide uploading for NPG authors, starting later this year. For details and to provide feedback, go to www.nature.com/press_ releases/archive.html. 